\title{
MINANGKABAU CLERGIES AND THE WRITING OF HADITH
}

\author{
Jannatul Husna bin Ali Nuar \\ University of Brunei Darussalam \\ jannatulhanuar.phd@gmail.com
}

\begin{abstract}
As one of the barns in the Islamic scholars throughout Indonesian archipelago, many Minangkabau scientists in the field of hadith had born figures spelled out with no exception. Trend of works by scholars of Minang in the field of hadith had also shown its own special evidences. Not only the work of translation and Sharh were generated, but also the original works in the field of hadith even drafted in Arabic. The main purpose of this article is to introduce a number of works on hadith and the science of hadith generated by the egg heads of Minangkabau, typically in the $20^{\text {th }}$ century. As for example, Professor Mahmud Yunus, Engku Mudo Zainuddin Hamidy, Ustaz Fachruddin Husain Datuk Majo Indo, Professor Zainal Abidin Ahmad, Buya Mawardi and Ustaz Muhammad Oemar Bakry Besar Datuk Tan. This study inspired cutting-edge scholars, even if they were graduates of local Surau and Madrasah, glorious hadith's books of high-value compilation were published similar to the context of riwayah-dirayah hadith, fiqh al-hadith or mushthalah hadith. The works were worthy triggers the spirit and inspiration of Muslim intellectuals today for innovation and transformation. In addition, the recent Muslim intellectual were exposed to a lot of formal higher education and academic degree holders, to be more productive in the delivering of similar treasury with the supports of sophisticated modern technology. Above all, the triggers should have been for the sake of preserving the writings of hadith in this beloved country.
\end{abstract}

Keywords: Ulama Minang, Work of hadith, Inspiration and Innovation

\begin{abstract}
Abstrak
Sebagai salah satu lumbung ulama di Nusantara, Ranah Minang banyak melahirkan tokoh ilmuwan terbilang tidak terkecuali dalam bidang hadis. Trend pengkaryaan hadis oleh ulama Minang menunjukkan coraknya yang khas dan tersendiri. Bukan saja karya terjemahan dan syarah yang dihasilkan, melainkan juga karya asli dalam bidang hadis bahkan disusun dalam bahasa Arab. Adapun yang menjadi tujuan utama artikel ini ialah memperkenalkan sejumlah karya hadis dan ilmu hadis yang dihasilkan oleh ulama Minangkabau, khususnya dalam abad yang ke-20, seperti Profesor Mahmud Yunus, Engku Mudo Zainuddin Hamidy, Ustaz Fachruddin Husain Datuk Majo Indo, Profesor Zainal Abidin Ahmad, Buya Mawardi Muhammad dan Ustaz Oemar Bakry Datuk Tan Besar. Kajian ini memberi inspirasi kepada sarjana mutakhir, bahwa sekalipun mereka adalah lulusan surau dan madrasah lokal, namun berhasil menyusun kitab hadis bernilai tinggi, baik dalam konteks hadis riwayah-dirayah, figh al-hadis atau ilmu mushthalah hadis. Karya-karya tersebut layak menjadi pemicu semangat dan inspirasi intelektual muslim dewasa ini untuk melakukan inovasi dan transformasi. Apatah lagi mereka banyak terdedah dengan
\end{abstract}


pengkajian formal dan bergelar akademik tinggi, agar lebih produktif dalam melahirkan khazanah seumpama itu dengan segala kecanggihan teknologi modern. Ini semua demi menjaga kelestarian penulisan karya hadis di negeri tercinta ini.

Kata kunci: Ulama Minang, Karya Hadis, Inspirasi, dan Inovasi

\section{Introduction}

It was unknown for sure when precisely the writing of hadith in Minangkabau was started. However, the early $20^{\text {th }}$ century had witnessed to be the new era in the preparation of compiling al-hadith in addition tothe Islamic jurisprudence, theology, Qur'anic exegesis and mysticism. Even though their works were the compilation of the introduction, translation or set of Prophet traditions, but the works had enriched knowledge of the Sunnah in West Sumatera. It maybe because of the shortage readings and investigations by the writer, as far as he is concerned, neither local reviewers nor abroad crowdedly reviewed the treasury tradition in the realm of producing these scholars. In fact, their role should not be ignored in developing the assessment in heritage of the traditions. The focus of the author of this article is to discuss the direction of development in the writing of the Prophet traditions and acknowledging among others, scholars of Minangkabau. This study is an initial introduction publicly about the works and innovations of the regional authors that may be developed by future generations. Although not all of them were categorized into experts on hadith (Muhaddith) in the definition of a perfect knowledge of mushthalah (memorized thousands of hadith, knowledgeable on fiqh alhadith, and was able to distinguish between authentic and fake-weak of hadith). But it is reasonable to introduce their works due to the responsibilities under pinned with their efforts. Therefore, it may be a very great duty for today's scholars to cultivate the restoration of their works. Humanity is like bricks' complementary in fostering the building to stand firmly, isn't it?

\section{Figures of Minang Scholars' Works on Hadiths Mahmud Yunus (1899-1982)}

He was known as a public figure of Islamic education and Arabic language as well as Qur'anic exegesis interpreter. The eldest son of two brothers practiced simple live and strongly hold religious and educational values. At the relatively young age (8 years old), he was appointed as a part time teacher at the Surau lead by his grandfather, Engku Gadang. ${ }^{1}$ In 1908, he studied both at the Village School and the mosque in Sungayang. He was unsatisfied with the lessons learnt over and over, he moved to Madras School in Tanjung Pauh, District of Sungayang which was newly established by Sheikh Muhammad Thaib Umar in November $4^{\text {th }}, 1910$ or in fourth of Zulkaidah, $1328 .^{2}$

Here, he studied Arabic grammatical rules, Mathematics focusing on fara'id system as well as Arabic conversation, and eventually appointed as a teacher and school leader of the same school due to the death of his beloved school principal. ${ }^{3}$ After teaching and leading the famous Madras School, in 1924 Yunus Mahmud went to Cairo to continue his ideals studying at the University of al-Azhar. In 1925 he passed the exams in 12 subjects of religion and the Arabic language and obtaining shahadah 'alimiyah or comparable degree of pious man

\footnotetext{
${ }^{1}$ Mahmud Yunus, Riwayat Hidup Prof. Dr. H. Mahmud Yunus: 10 Pebruari 1899-16 Januari 1982 (Jakarta: Hidakarya Agung, 1982).

${ }^{2}$ Mahmud Yunus, Sejarah Pendidikan Islam di Indonesia (Jakarta: Pustaka Mahmudiah, 1960), 55.

${ }^{3}$ Ibid., 129-130; Ramayulis dan Samsul Nizar, Ensiklopedi Tokoh Pendidikan Islam: Mengenal Tokoh Pendidikan Islam di Dunia Islam dan Indonesia (Jakarta: Quantum Teaching, 2010), 322-323.
} 
as a Sheikh. ${ }^{4}$ His spirit of learning was never extinguished. In 1926, he was offered to study at the Darul 'Ulum, Cairo. He was the first student from Indonesia (so-called the Dutch East Indies) even became one of foreigners who managed to enter and obtained teacher diploma (diploma Tadris) in 1930 and was also recognized as the recipient of the highest marks in the subject of insha' (composing).

He returned to his homeland in 1931 and directly managed the educational institution or $a l$ Jami'ah al-Islamiyah in Sungayang and Normal Islam in Padang. He also mandated an important position as chairman of the board of the Islamic Educational College in Padang (1940-1942); Dean of the Official Academy of Religious Sciences in Jakarta (1957-1980); Dean and Professor at the Faculty of Tarbiyah and education, The State Institute of Islamic Studies (IAIN) Jakarta (1960-1963); Rector IAIN Imam Bonjol Padang (1967-1970), and several other responsibilities. Owning the fact that many services he held, he was awarded an honorary doctorate (Dr. HC) in education on October 15, 1977 by IAIN Ciputat, Jakarta. According to Federspiel, Professor Mahmud was very popular for his work on Islamic education in Indonesia and the writer of books on the use of hadith. In addition, as a constituent of Qur'anic Exegesis books. These monumental works had been reprinted up to 23 times. This means that the treasures of his interpretation remains the most famous references, even though there had been the deeper work of other Qur'anic interpretation books than his which were somewhat more scientifically written. ${ }^{5}$ As a writer, there had been 63 works produced which consisted of 49 books in Indonesian and 27 in Arabic, including Islamic

\footnotetext{
${ }^{4}$ Mahmud Yunus, Tafsir Quran Karim, cet. 19 (Singapore: Basheer Ahamed, 1979), iii.

${ }^{5}$ Howard M. Federspiel , Kajian Al-Quran di Indonesia Dari Mahmud Yunus Hingga Quraish Shihab, Tajul Arifin (pent.), cet. 2 (Bandung: Mizan, 1996), 104, 130.
}

religious sciences, education and Arabic. ${ }^{6}$ According to Irhas Samad, precisely he had spawned 82 treasures of the work since the period of 1920 to 1982, which included books on fiqh and usul al-fiqh, Arabic, interpretation, Islamic education, morals, monotheism and history. From a number of essays that once had been discussed (topics on hadith and the science of hadith) in particular, such as:

First, Mustalah Ilm al-Hadith (written in Arabic). This book explained the conception of the science of hadith which was understood from its title. It was the Arabic-language work composed by him in December 25, 1940 (26 Zulkaidah 1359) and completed in Sungayang on 10 April 1941 (13 Rabiulawal 1360) in Padang. ${ }^{7}$ The contents of the discussion began with the science of hadith dirayah-riwayah and ended with a brief review of the hadith qudsi. The background of the preparation of this book was driven by a desire to avail for students of religious schools. As stated in the book's preamble:

$$
\begin{aligned}
& \text { فهذه رسالة صغيرة في علم مصطلح الحديث ,لحصتها من الكتب } \\
& \text { المطولة ليستفيد منها الطلبة ويراجعها المدرسون في المعاهد الدينية,, } \\
& \text { وأرجوا أن تقع موقع القبول والله المسؤول }
\end{aligned}
$$

Meaning: This is a small treatise on the science of mushthalah al-hadith formulated from thick books to be beneficial for students and be used as a reference by educators in various religious schools. I hope this book could be well received and only God nevertheless to crave for prayer (the best). ${ }^{8}$

A third edition book consisted 105 pages was used as the reference printed by Maktabah Sa'adiyah, Padang Panjang in 1969. The reference was obtained from his teacher, Professor Edi Safri

\footnotetext{
${ }^{6}$ Ramayulis dan Samsul Nizar, 324.

${ }^{7}$ Mahmud Yunus, 'Ilm Mustalah al-Hadith, cet. 3 (Padang Panjang: Maktabah Sa'adiyah, 1969), 4, 105.

${ }^{8}$ Ibid., 4.
} 
at IAIN Imam Bonjol Padang. However, the collection in the library of UIN Jakarta was found an edition in 1971 with the classification code of 2X2.I YUN i.

Second, Musthalah Science of Hadith (written in Indonesian). The preliminary remarks wrote that the work was completed in Jakarta consisting of 90 pages in July 30, 1958 (13 Muharam 1378). ${ }^{9}$ The book was a joint work with Mahmud Aziz that was published by PT. Jayamurni, Jakarta. The physical editions were published in 1958 ( $1^{\text {st }}$ Edition), 1959 ( $2^{\text {nd }}$ Edition), 1961 ( $^{\text {rd }}$ Edition), 1966 (4 ${ }^{\text {th }}$ Edition), 1970 (5 $5^{\text {th }}$ Edition), 1972 ( $6^{\text {th }}$ Edition), 1974 ( $7^{\text {th }}$ Edition), 1975 ( $8^{\text {th }}$ Edition) respectively. This had proven that the printing frequency of such a literature was quite captured in the hearts of learners. Writer of this paper referred to the $8^{\text {th }}$ Edition (1975) of this book which was found in the Library of the National University of Malaysia. Discussing on the purpose of writing books, the major aim is to provide convenience for the students of PGA, SGHA and secondary madrasahs in understanding the object of the science of hadith which was much compiled in Arabic. Moreover, this work is also suitable for the learners who want to know the theory of the science of hadith. In addition, terms used in the mushthalah hadith as valid, hasan and weak can be clearly understood, besides dealing with muda' af hadith (the hadith which is weak in both text and narrator); Hadith salih is less degree of hasan but was not categorized too weak. ${ }^{10}$ At the end, there will be a brief overview of the background of the famous hadith scholars among Muslims including those narrated by alBukhari, Muslim, Abu Dawud, al-Tirmidhi, alNasa'i, Ibn Majah, and Ahmad.

Third, Doa-doa Rasulullah s.a.w., a booklet containing 31pages inspired readers about the daily prayers and $z i k r$ accompanied by it

\footnotetext{
${ }^{9}$ Mahmud Aziz dan Mahmud Yunus (1975), Ilmu Musthalah Hadis, cet. 8 (Jakarta: Jayamurni, 1975), 6. ${ }^{10}$ Ibid., 29-30.
}

translation. Although physical existence of the book was very thin and simple, but very useful for low-grade students because most of the prayers were taken from Hadith Rasul peace be upon him and partly from the Qur'an. This book was written by the author in Jakarta on March $17^{\text {th }}, 1975$ (4 Rabiulawal 1395) and was published by PT. Hidakarya Agung, Jakarta five years later (1980/ 1400).

Fourth, Morals in the Koran and the Hadith. This book was the range of ethical issues in the perspective of the Qur'an and Hadith. However, the work has not been found and was believed as one of the essays by Professor Mahmud which had been published in 1978 by Hidakarya Agung, Jakarta, the publisher belonged to the concerned author.

After spreading immeasurable devotion, the famous author born in Sungayang, Batusangkar on Saturday, February $10^{\text {th }}, 1899$ (30 Ramadan 1316) ${ }^{11}$ had passed away on Saturday, January 16 , 1982 (20 Rabiulawal 1402) $)^{12}$ in Jakarta at the age of 83 years.

\section{Engku Mudo Zainuddin Hamidy (1907-1957)}

Personal well-known as an expert in Qur'anic Exegesis and Hadith and also an alQuran memorizer had short-lived but really means. When he was a child, Engku Mudo had recognized letters of hijaiyah, learnt to read alQur'an, practiced of worship, such as taking ablution and praying five times a day, learnt the stories of Prophet and pious persons at the mosque around his house. Additionally, Zainuddin was sent by his father to the Government School to study general knowledge in the morning and to deeply learn religious knowledge in the afternoon. Having been a formal education at Dutch schools

\footnotetext{
${ }^{11}$ Ramayulis dan Samsul Nizar, 321.

${ }^{12}$ Eficandra Masril, "Prof. Dr. H. Mahmud Yunus: Tokoh Mujaddid dari Minangkabau" (Makalah dalam Nadwah Ulama Nusantara IV: Ulama Pemacu Transformasi Negara, Jabatan Pengajian Arab dan Tamadun Islam, Fakulti Pengajian Islam, Universiti Kebangsaan Malaysia, 25-26 November 2011).
} 
for five years. ${ }^{13}$ After graduating from Government School, he continued his studies at Sumatra Padang Thawalib Japang (established in 1906). This school was an initiative of Sheikh Abdullah in 1854 which was developed by his son, Sheikh Abbas and Sheikh Mustafa and experienced successful period in applying the classical system. Since Sumatra Thawalib was affiliated from purely educational to political organization, Sumatra Padang Thawalib Japang remained as early purposes of its establishment and was forced to change its name to be Madrasah Darul Fonun el-Abbasid since 1930 until now. ${ }^{14}$ A man of thirst for knowledge went to the Holy Land to perform Hajj in 1927 and studied at Ma'had Islami, Mecca. There was no complete information about the history of the school in conjunction with his teachers there. However, he is said to be the first Indonesian accepted to study at the school. ${ }^{15}$ In addition, he participated with halakah in the Masjid al-Haram. Since 1932, he had returned to his homeland to devote services in education and religion.

His return at 25 years of age had been encouraging people to call him Engku Mudo, a worthy and capable young man in the field of Islam. He was appointed as an Imam at Masjid Gadang, Koto Nan Ampek. The first change he made was a tradition of khutbah in Arabic replaced by him using Indonesian. In addition, he also turned on the congregational prayers, assembling parishioners for science of Islam, commemorating Islamic holidays, and teaching as well as leading Diniyah School Koto Nan Ampek to look up into advance becoming Ma'had

\footnotetext{
${ }^{13}$ Nukman, "Profil Syekh Haji Zainuddin Hamidy" dalam Edwar (ed.), Riwayat Hidup dan Perjuangan 20 Ulama Besar Sumatera Barat (Padang: Islamic Centre Sumatera Barat, 1981).

${ }^{14}$ Mahmud Yunus, Sejarah Pendidikan Islam di Indonesia, 144-145.

${ }^{15}$ Hikmat Israr, Angku Mudo Haji Zainuddin Hamidy: Pejuang Agama dan Pendiri Ma 'had Islamy Payakumbuh (Bandung: Budaya Media, 2010), 31.
}

Islami. ${ }^{16}$ A number of people had recognized him as a great young man, including an award he received from the Governor of West Sumatra, Azwar Anas and held a Warrior of Religion (1978). In addition, Buya Hamka used to raise him with a compliment, as quoted by Hikmat Israr:

Without prejudice towards my award to the other scholars. It appears to me, as I know him for 25 years. Shaikh Zainuddin Hamidy is one of the time-tested religious pioneers, pedestal hope of job as a torch in broadcasting the holy ideals of Islam throughout the country. ${ }^{17}$

His actual persona was approved with the heritage treasures, i.e. the largest and monumental was A Quranic Exegesis: The Original ScriptTranslate-Specification (1955). While in the field of hadith, such as Translation of Valid Hadith of Bukhari (Volume 1-4), 40 Selected Hadith: Syarah and Musthalah Hadith.

First, Translation of Valid Hadith of Bukhari (Volume 1-4). He translated a number 2027 hadiths accompanied by Fachruddin HS, Djohar Arifin, Nasharuddin Taha and Abd. Rahman Zainuddin. The book was completed in Payakumbuh in March 1937 (Muharam 1358). First edition was published in 1937 by Firma Widjaja, Jakarta in cooperation with CV. Wicaksana, Semarang. Then, the successive editions ( $2^{\text {nd }}$ Edition) were printed in 1951 ; $\left(3^{\text {rd }}\right.$ Edition) in 1953 ; (4 ${ }^{\text {th }}$ Edition $)$ in $1954\left(5^{\text {th }}\right.$ Edition $)$ in 1958 ; $\left(6^{\text {th }}\right.$ Edition $)$ in 1961 ; $\left(7^{\text {th }}\right.$ Edition $)$ in 1964 ; ( $8^{\text {th }}$ Edition $)$ in $1969 ;\left(9^{\text {th }}\right.$ Edition $)$ in $1981 ;\left(10^{\text {th }}\right.$ Edition) in 1983 ; (11 $1^{\text {th }}$ Edition) in 1984 ; $\left(12^{\text {th }}\right.$ Edition) in 1986 , and $\left(13^{\text {th }}\right.$ Edition or Special edition) was published in 1992. The reference used by the writer was a book published in 2009 by Darel Fajr Publishing House No. 37 Geylang Road, Singapore - ISBN 983-40440-6-2.

\footnotetext{
${ }^{16}$ Ibid., 42.

${ }^{17}$ Ibid., ii.
} 
Second, 40 Selected Hadith: Syarah and Musthalah Hadith was the work of translation of al-Nawawiyah Arba 'in by al-Nawawi containing 42 hadith. Between the uniqueness of the work which totaled 126 pages and published first by Jayabakti Publisher, Jakarta in 1956 - was the prayers dedicated to Prophet Muhammad PBUH with the great lord (سلم وآله عليه الله صلى) by which the Arabic calligraphy was a hand writing written by H.M. Jasin; the book costonly Rp. 22 at the time. This collection of intellectual included a scarcely work. However, it had been out of printed so that no later addition published by the publisher today. Even, the family did not keep any copy of it. Luckily, the writer found a single copy in the Library of the International Islamic University Malaysia with the classification number BP135 A3 A136E 1956. The content of this book was literally translation from the book of Sharh hadith written by al-Nawawi. The style of writing was the original writing style including ranking of the sanad companions, text of the hadith and mukharrij, the translation of the hadith text; signification of the Sharh hadith were exactly referred to Hadith I to XLII in the Sharh of Iman al-Nawawi. Furthermore, in explaining the brief introduction of the personality of al-Nawawi, the translator referred to Sharh al-Ahadith al-Arba'in Nawawiyah alShaykh al-Taftazani. The treasure was completed in Sionjak (Sionyak), Payakumbuh on June 7, 1956 (27 Shawwal 1375) using similar gratitude to Allah SWT as stated in the original text as follows:

With God's help and His Blessings, the book was completely translated into Indonesian. May God accept this as righteous deeds, and there will hopefully be useful valuable contribution to the knowledge of religion in Indonesia.

Third, Musthalah Hadith. Evidently, it is rarely found the great works that had ever been produced as such also justified by his son, Ramzi
Zainuddin. $^{18}$

The history of inspired scholar, Engku Mudo Zainuddin, who was born in Koto Nan Ampek, Payakumbuh on Thursday, February 7, 1907 (23 Dhulhijjah 1324), had been returned to the presence of the divine of one morning on Friday, March 29, 1957 (27 Sha'ban 1376) at the age of approximately 50 years old. The late successor was buried at cemetery of the Islamic Ma'had, Jalan Soekarno Hatta No. 20 Koto Nan Ampek, Payakumbuh.

\section{Ustadz Fachruddin Husain (1908-1987)}

Ustadz Fachruddin Husain (1908-1987) was one of a prominent freedom fighters and a leading scholar in Minangkabau. He held a customary title "Datuk Indo Majo" and also an offspring of clergy. Born as the eldest of two brothers in Situjuh Batur, Payakumbuh on Friday, June 5, 1908 (5 Jumada 1326) and died in Jakarta on Monday, August 3, 1987 (7 Zulhijah 1407) at the age of approximately 80 years. ${ }^{19}$ Tuanku Husain Khatib, his father was the first teachers who taught alQur'an and Arabic-Malay scripts. As a child of a clergy, he was often taken by his father to go preaching to the various niches of the region. After completing his primary education, he studied a non-formal education with several religious teachers in the village of his birth. He studied with Engku Mudo Hamzah in Air Adieu (1921-1922). He was also studying with Engku Mudo Ahmad Karungin 1923-1927. The intention of his mother and father to send to study in the Holy Land of Mecca subtly declined by him for no apparent reason. He would presumably prefer to study at a regular school and intentionally deepened his knowledge throughout one to other scholars in several Surau in the Land of Minang. The late father of a Supreme Court Judge, Irfan Fachruddin, was known as the five series scholars with other four figures, such as Zainuddin

\footnotetext{
${ }^{18}$ Ramzi Zainuddin, Interview, 02 July 2012.

${ }^{19}$ Fachri Fachruddin, Interview, 7 March 2015.
} 
Hamidy, Nasharuddin Taha, Arisun Sutan Alam, and Dervish Taram. All five frequently held meetings to discuss the socio-political developments, particularly focusing on the national self-esteem and the concrete steps to reach independence. Besides of course they explored religious issues. Finally, these fivefigures had successfully triggered the establishment of Indonesian Muslim Intellectual Association, who managed the branch office in Payakumbuh, which was then famous by PERMI of 50 Cities. The association was leaded by Haji Fachruddin HS at that time.

Instead of his movement in the realm of practical policy, he was also active in activating Islamic Affairs. Issues such as the Wild School Ordinance, the Marriage Civil Record and Ordinance Teacher preached by the colonial helped stimulating the fighters' spirit of characters, including Ustaz Fachruddin. Although the atmosphere was so precarious, Fachruddin HS preferred the somewhat "soft" to communicating speeches and lectures. As a result, the force of style remained the injected hopes of escaping the shackles of confinement from invaders. During his life, in addition to preaching and becoming a political party member, he did not miss producing scholarly works. It was mentioned, Faith and Life (translation from Al-Iman wa al-hayah by Sheikh al-Qaradawi); Forming Qur'anic Moral Guidance published by Bina Aksara in 1985; Quranic Exegesis; Original Script-TranslateSpecification (accompanied by Zainuddin Hamidy et.al). While on the discipline of Hadith, i.e. Translation of Sahih Bukhari (4 Volumes) jointly completed with Zainuddin Hamidy, et al); Options Word of Rasul (The Selected Hadiths) (translated from al-Ahadith al-Mukhtarah written by Shekh al-Hashimi and Irfan Fachruddin, consisted 616 pages and was published by Bumi Aksara, Jakarta in 1996 and the Translation of Sahih Muslim (4 Volumes).

Having exposed the Translation of Sahih Muslim, this work was categorized into literal translation without additional Sharh. It consisted of four volumes in which the first volume contained 293 pages. It was the only one volume published by C.V. Bulan Bintang, Jakarta in 1978. In this section, we were told that biography of Muslim and a number of hadiths which were translated up to 446 hadiths. When the second volume (270 pages) was published by the same publisher in 1979, 378 hadiths summarized the translation. Next, the third volume with 217 pages, published by the same publisher in 1979, included over 375 translations of hadith. While the fourth volume consisting of 220 pages was published in 1979 by the same publisher, containing the translation of 364 hadiths. He translated over 1563 hadiths into Indonesian language was that due to the messages of Prophet Muhammad PBUH in Sahih Muslim as the major literature of hadith after Sahih al-Bukhari-also could be understood by many Indonesian in general and the Moslems in particular who did not understand Arabic. ${ }^{20}$

\section{Zainal Abidin Ahmad (1911-1983)}

He was well-known as a political figure as well as a senator. Born in Sulit Air, Solok on Tuesday, April 11 ${ }^{\text {th }}, 1911$ (11 Rabiulakhir 1329) and passed away at the Islamic Hospital in Jakarta on Tuesday, April 26 $6^{\text {th }}, 1983$ (13 Rajab 1403) ${ }^{21}$ at the age of 72 years old. After a basic religious education at the Surau and the public education of Government School around the village, he continued his academic adventure to Sumatera Thawalib Padang Panjang in 1924 until graduation in 1928. Here, he was raised by a teacher-caliber scholar, such as Sheikh Abdul Karim Amrullah and Engku Mudo Hamid. Among other Minangkabau Scholars who had authored more or less 40 books, was a leader of the Indonesian parliament (1950-1960),

\footnotetext{
${ }^{20}$ Fachruddin HS, Terjemah Hadis Sahih Muslim 1. (Jakarta: Bulan Bintang, 1978), 5.

${ }^{21}$ Soebagijo Ilham, Riwayat Hidup dan Perjuangan Haji Zainal Abidin Ahmad (Jakarta: Pustaka Antara, 1985), 215.
} 
pioneering his career as a journalist from 1934 to 1957. His career as an educator began in 1929 when he was appointed as teachers at Sumatra Thawalib Padang Panjang and ended when the Dutch colonials issued a letter of warning him and a number of his other colleagues to teach in 1934. ${ }^{22}$ The highlight of his devotion exactly happened when he was appointed as a professor of religious proselytizing science at the Institute of Da'wah Islamiyah al-Qur'an (IIQ), Jakarta in 1982 and he became rector of the College of the Qur'an (PTIQ), Jakarta since 1980 until the final day of life in 1983. Professor Zainal rested his interest in history, in addition to preparing the work of political science and state craft. Among the quite important of his works were that The Autobiography of Avicenna, The Autobiography of Imam Ghazali, The Autobiography of Averroes, Guidelines for Political Sciences, and Islam and Parlementaria. In the field of the Science of Hadith, he wrote Imam Bukhari: Apex of the Science of Hadith.

The book entitled Imam Bukhari: Apex of the Science of Hadith was the result of his lectures when commemorating the birth of Imam Bukhari on 13 Shawwal 194/21 July $810=13$ Shawwal 1394/15 November 1974 or 1200 years' time. The commemoration was carried out at Taman Ismail Marzuki, Jalan Cikini Raya 73, Jakarta by inviting two panel speakers such as Zainal Abidin Ahmad who delivered his article "The Biography of Imam Bukhari". While the second panel, Abd. Wasit Aulawi, MA discussed "The System of Filtering Hadith and Its Influence of Works of Imam Bukhari on Syara' Legal Developments". A discussion of the Hadith as the basis of Islam after al-Qur'an was a number of additional topics in order to meet the desires of readers. He also made a discussion of the Hadith at the time of the Prophet, the development of the science of hadith, Imam Bukhari: Apex of the Science of Hadith (including the background of life and the

${ }^{22}$ Ibid introduction to Sahih al-Bukhari) and the tragic end of life. The book about 140 pages was equipped with an attachment featuring of committee report on the $12^{\text {th }}$ Century Anniversary of Imam al-Bukhari, articles of second speaker as well as the index. The treasures were firstly printed in 1975 by Bulan Bintang Publisher, Jalan Kramat Kwitang I/8, Jakarta.

\section{Buya Mawardi Muhammad (1913-1994)}

He was among the scholars of hadith from Minangkabau. His life totally dedicated to the world of education and writing. In addition to being a teacher in Thawalib Padang Panjang, he was also a lecturer of the State Institute of Islamic Studies Imam Bonjol, Padang who delivered thousands of graduates engaging in various fields of life. After completing his primary education in his hometown, this devotee of knowledge continued his study in Sumatra Thawalib and Diniyah School, both in Padang Panjang, and graduated in 1930. Although he never got knowledge directly from the Middle East, but he had been raised by local Islamic scholars in advance with a great Sheikh Abdul Karim Amrullah, Engku Mudo Hamid, Buya Djalaluddin Thaib, Buya Doeski Samad and Professor Zainal Abidin Ahmad.

As a public figure whose life was mostly dedicated to provide the foundation in the field of hadith, he had spawned a number of articles in the discipline of knowledge that covered the field of the science of hadith, a collection of books on Hadith and Its Sharh, both in Arabic and Indonesian, such as:

\section{Hidayah al-Bahith fi Mustalah al-Hadith. This} book was among the best ever works created by Malay scholars. The completed writing was dated on Monday, April 20 ${ }^{\text {th }}, 1936$ (28 Muharam 1355). ${ }^{23}$ This was his second work

\footnotetext{
${ }^{23}$ Mawardi Muhammad, Hidayah al-Bahith fi Mustalah alHadith, cet. 11 (Bukittinggi: Pustaka Sa'adijah, 1972), 98.
} 
after the Proceedings of Fasting of the Prophet (1934) which discussed the science of mustalah al-hadith. It was first published in Bukittinggi by Maktabah Sa'adiyah. It had also been printed by Maktabah Sa'adiyah Putra in Padang Panjang and Jakarta (consisting of 120 pages) and without year of publication. The writer cited the $11^{\text {th }}$ Edition as the reference published by Maktabah Sa'adiyah Bukittinggi in 1972/1392 which contained 102 pages.

2. Jawahir al-Ahadith. The origin title of this book was Jawahir al-Ahadith al-Nabawiyah ${ }^{24}$ was completed in 1937. It was printed by the Tandikat Publisher of Padang Panjang up to the $7^{\text {th }}$ editions and also without year of publication. There were about 147 pages covering with 493 hadith and accompanied by Fihris and Erata (taslih al-khata').The first Hadith dealt with "al-Ikhlas" and ended up with the hadiths related to "al-ad'iyah".

3. al-Ahadith al-Mukhtarah 1-3. The book was a trilogy work consisting of three sections (chapters). Each of these chapters contained 40 pieces of hadith. The book was organized for the syllabus of Madrasah Thanawiyah throughout Indonesia at the time. The completion of writing was completely done in 1951 and then it was printed by Sridharma Printing, Padang without year of publication. As for the writer's reference was ideas stated

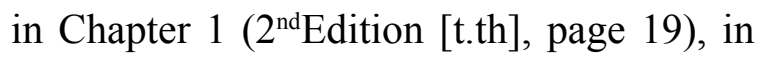
Chapter 2 (2 Edition [t.th], page 21), and Chapter 3 ([t.th], page21).

4. Mushthalah Science of Hadith. This book was finalized on June $5^{\text {th }}, 1957 .{ }^{25}$ This book was a translation version from Hidayah al-Bahith with a number of additions in some parts of it

\footnotetext{
${ }^{24}$ Mawardi Muhammad, Jawahir al-Ahadith alNabawiyah, cet. 7 (Padang Panjang: Penerbit Tandikat, t.th.), 3 .

${ }^{25}$ Mawardi Muhammad, Ilmu Mushthalah Hadis (Bukittinggi: Pustaka Sa'adijah, 1957), 95.
}

and had been several times reprinted. Its first publication was in 1957 by Maktabah Sa'adiyah, Bukittinggi (98 pages) using old Indonesia phone me's spelling. This book was also printed by Sridharma Printing, Padang in 1981 ( $7^{\text {th }}$ Edition, 128 pages); and it had also been published by Sa'adiyah Putra, Padang Panjang in 1966 containing 117 pages.

5. al-Ahadith al-Mukhtarah wa Sharhuha 3-6. This book was among his quite important works in the field of hadith. The author not only attached Hadiths, but also suggested Sharh of its own comprehending. It consisted of four sections: the third section consisted of 21 Hadith with 32 pages, the fourth section consisted of 20 Hadith with 32 pages, fifth section consisted of 26 Hadith with 49 pages, sixth section consisted of 20 Hadith with 52 pages. This book was first written in 1950s while sixth section was perfectly prepared on 12 September 1975 (6 Ramadan 1395). ${ }^{26}$

It was published in Padang Panjang by Sa'adiyah \& Son Publisher, without year of publication.

6. Ma'ani al-Hadith. Description of this book was one of his works from manifestation of his student, Dr. Syar'i Sumin. But the writer was so far unable victoriously identified the book. By comparing with the description of his other student, the writer found a bright spot that "the study of the meaning of the Hadith" was a course he taught, instead of the headline of his composition.

In addition to the above works, he also compiled the work in other fields, for example Proceedings of Fasting of the Prophet, Fiqh Mawarith, al-'Arud al-Wadihah, al-Usul alNahwiyah, Sabil al-Zarf fi 'Ilm al-Sarf, Ma Fi 'rifah al-Fasahah wa al-Balagha,' Ilm al-Tafsir,

\footnotetext{
${ }^{26}$ Mawardi Muhammad, al-Ahadith al-Mukhtarah wa Sharhuha (Padang Panjang: Penerbit Sa'adiyah Putra, t.th), 50 .
} 
and educational papers. Why was he able to produce brilliant works? The mastery of knowledge instruments (Arabic Language) very well alleged to be the key of scientific treasures. It apparently seemed not enough for only mastering the spoken language, but also it must be the connected instrument to learn more Islamic mosaics.

After conducting great efforts of the glorious history on the stage of preaching, education and writing, the charismatic cleric who was born in Kubang Putih, Bukittingi on Friday, October $10^{\text {th }}$, 1913 (9 Zulkaidah 1331) had his last breath at the Islamic Hospital, Bukittinggi on Friday, December 30, 1994 (27 Rajab 1415) at the age of 81 years old. His body was interred on the left side of Mosque Mihrab of College Thawalib Padang Panjang.

\section{Ustadz Oemar Bakry (1916-1985)}

Ustaz Oemar Bakry, known as Datuk Tan Besar, was born in Kacang-Solok, on Monday, June 26 ${ }^{\text {th }}, 1916$ (24 Sha'ban 1334) and passed away in Bandung on Friday morning, April $19^{\text {th }}$, 1985 (28 Rajab 1405) at 69 years old. His body was interred in the cemetery of Tanah Kusir, Southern Jakarta. ${ }^{27}$ After attending primary school in his village, Oemar Bakry forwarded to study at Diniyah School Thawalib Sumatra in Padang Panjang. He graduated from Diniyah School in 1931 and at Sumatra Thawalib in 1932, he then studied at Kuliyatul Muallimin Islamiyah Normal Islam, Padang lead by Professor Mahmud Yunus and he graduated in 1936 and held first class honor. Then, he made a second fortune at the Faculty of Literature, University of Indonesia, but he did not graduate there.

His academic career began when he was appointed as a teacher at College Thawalib Padang Panjang in 1933 up to 1938. In 1937 he was appointed a director of Muhammadiyah

${ }^{27}$ Fahmi Oemar, Interview, 22 July 2012 and 31 Oct 2012.
School of Teacher Training in Padang Sidempuan. On January $21^{\text {st }}, 1938$, he founded and acted as a director of Public Typewriting School in Padang Panjang. This institution was later renamed to be Taman Kemajuan. In addition to being a teacher, he was also a preacher. West Sumatra, Jakarta and Bandung were places he used to spread the messages of religion. He was getting a wellknown figure through oral and written preaching. Especially, when he commented the work of H.B. Yasin, Al-Qur'an al-Karim Bacaan Mulia in 1978. Having been the preacher in his own country, he used to give lecture at the University of Al-Azhar, Egypt in December 22 $2^{\text {nd }}, 1983$ besides he was also a keynote speaker at the State Islamic Institute of Sunan Ampel Surabaya on February $11^{\text {th }}$, 1984; at the State Islamic Institute of Imam Bonjol Padang on March 26 ${ }^{\text {th }}$, 1984; and at Bung Hatta University Padang on $28^{\text {th }}, 1984$. Beside he was an instructor, he was also an owner of a Printing Offset (PT. Mutiara Jakarta dan CV. Angkasa Bandung). He remained a productive author both in Arabic and Indonesian. Ther were 30 works he had produced during 1930 until 1980 s. ${ }^{28}$ All the best works he had written were Tafsir Madrasi (Arabic Version), Tafsir Rahmat (Jakarta: Mutiara, 1984 ( $3^{\text {rd }}$ Edition), Dari Thawalib ke Dunia Modern, al-Ahadith alSahihah (Arabic Version), and Uraian 50 Hadith.

It was mentioned by the author himself that the Uraian 50 Hadith was the translation of his previous book al-Ahadith al-Sahihah which was compiled in 1938. The book was started to be compiled in June 1981 after he had surgery at Cikini Hospital Jakarta. The book was uniquely written by his wife (Hj. Nurjannah) through tape

\footnotetext{
${ }^{28}$ Jannatul Husna bin Ali Nuar, Ustaz Haji Oemar Bakry dan Uraian 50 Hadis (Jakarta: Mutiara Sumber Widya, 2015), 14-18.

${ }^{29}$ Oemar Bakry, Dari Thawalib ke Dunia Modern (Jakarta dan Bandung: Penerbit Mutiara dan Angkasa, t.th), 490492.
} 
recorder. ${ }^{29}$ The preface dated November $10^{\text {th }}, 1982$ meaning that the was completed within only five months (June-November) then was published by Mutiara Printing Jakarta in 1981. This book became major reference of the writer lent by son of Ustadz Oemar Bakry, Fahmi Oemar which physically consisted of 95 pages and size of 14,8 $\mathrm{cm}$ and $21 \mathrm{~cm}$. At its initial discussion, the book contained topics on "The Miracle of Advice" until the $50^{\text {th }}$ hadith about "Taking Care of Tooth Health." When the compilation style of the book was seriously observed, the author seemed mostly apply global and simple method of discussion with high-frequency words used for pubic and students. He addressed the writing of hadith accompanied by its translation and short remarks about the significance of the narrated Prophet traditions.

\section{The Characteristics of the Works of Hadith by Minang Scholars}

Table 1 shows the characteristics of the works of hadith by Minang scholars during the decades of 1920s until 1990s.

Table 1: The Characteristics of the Works of Hadith by Minang Scholars

\begin{tabular}{|c|c|c|c|}
\hline No. & Titles & Kind of Works & Percentage \\
\hline 1. & Imam Bukhari: Pemuncak Ilmu Hadis & Biography of Clergy & $6 \%$ \\
\hline 2. & Doa-Doa Rasulullah & Thematic Hadith & \multirow{2}{*}{$11 \%$} \\
\hline 3. & Akhlak Menurut al-Qur'an dan Hadith & Thematic Hadith & \\
\hline 4. & 'Ilm Mushthalah Hadis & Mushthalah Hadis & \multirow{5}{*}{$28 \%$} \\
\hline 5. & Ilmu Mushthalah Hadis & Mushthalah Hadis & \\
\hline 6. & Musthalah Hadis & Mushthalah Hadis & \\
\hline 7. & Hidayah al-Bahith & Mushthalah Hadis & \\
\hline 8. & Ilmu Mushthalah Hadis & Mushthalah Hadis & \\
\hline 9. & Jawahir al-Ahadith al-Nabawiyah & Compilation of Hadith & \multirow{2}{*}{$11 \%$} \\
\hline 10. & Al-Ahadith al-Mukhtarah (1-3) & Compilation of 40 Hadith & \\
\hline 11. & Al-Ahadith al-Mukhtarah wa Sharhuha 3-6 & Sharh Hadith & \multirow{4}{*}{$22 \%$} \\
\hline 12. & Ma'ani al-Hadith & Sharh Hadith & \\
\hline 13. & Al-Ahadith al-Sahihah & Sharh Hadith & \\
\hline 14. & Uraian 50 Hadis & Sharh Hadith & \\
\hline 15. & Terjemah Hadis Sahih Bukhari 1-4 & Translation & \multirow{4}{*}{$22 \%$} \\
\hline 16. & 40 Hadis Pilihan Dengan Syarahnya & Translation & \\
\hline 17. & Terjemah Hadis Sahih Muslim (1-4) & Translation & \\
\hline 18. & Pilihan Sabda Rasul & Translation & \\
\hline
\end{tabular}


Among the six Minangkabau clergies of hadith identified in this study, the writer had successfully mapped the existing kinds of work, i.e. there was one book (6\%) on The Biography of Minangkabau Hadith Clergies, two books on the hadith with particular themes (11\%), five books on Musthalah Hadith (28\%), two books on Compilation of Hadith (22\%) and so were books on Translation (22\%). There were seven books written in Arabic (39\%). This means that the works on Hadith in Minangkabau mostly dominated by the use of mother tongue (Indonesian) which was stated about eleven books (61\%). The five books of hadith (28\%) written in Arabic by Mawardi Muhammad seemed to be a bit unique comparing to the works by Mahmud Yunus and Oemar Bakry which produced only one book respectively. In addition, Mawardi Muhammad wrote a number of hadith works in several sections. Beginning from the great works of both "The Translation of Shahih Bukhari"and "The Translation of Shahih Muslim" consisting of the former was containing 2027 hadiths and the later was 1563 hadiths. Each book was comprising of four volumes.

The writer realizes that the existing works were categorized as "introduction entry" rather than those works which more critical and swooped performance. Even though their works were still ijmali (shortage), but very much suited with the needs of readers and students at that time. The literally entries in the translation of hadith books by most Minangkabau clergies had its own character and category. None of the interpretation was in conjunction with the work by Syekh al-Marbawi in Bahr al-Madhi as well as Sahih al-Bukhari, Shahih Muslim, Arba'in Nawawi, and al-Ahadith alMukhtaroh narrated by Shekh al-Hashimi.

\section{Figure 1: Characteristics of teh Works of Hadith by Minagkabau Clergies}

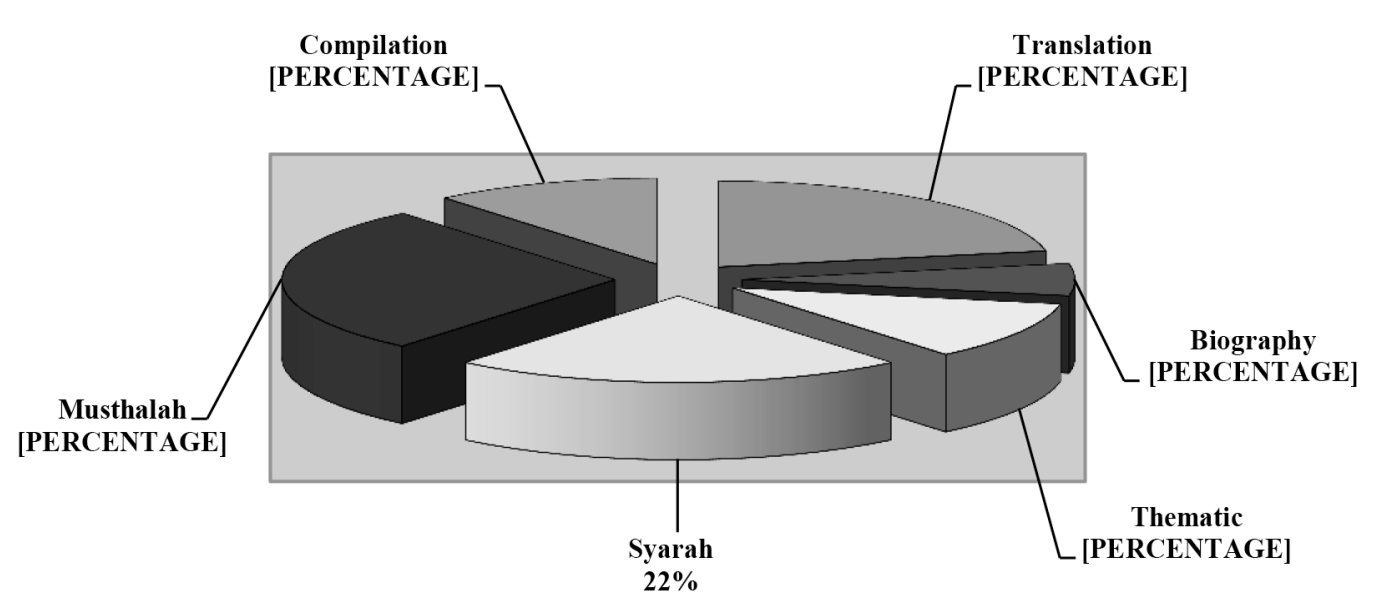

Nevertheless, the writer had not found yet the study of the Sunnah dissenter in Minangkabau, either the introduction of the causes or solutions offered. However, a figure such as Professor Edi Safri Datuk Panduko Sati realized or become anxiety and concerns of whom then examine the former movement against the sunnah performed by Dalimi Lubis. Even the former Minangkabau clergies rarely touched "infighting" in the hadith and how to overcome it. The object of "mukhtalif al-hadith" like this used to be mounted by academician, Datuk Panduko Sati when he attended for doctorate degree at the State Islamic Institue of Jakarta in the late 1990s, also can be compared with other campus scientist, such as Professor Nawir Yuslem. It seems clear that the early scholars of the 20th century did not examine many hadith analytically and look only for a 
suitable methodology to be applied in understanding the hadiths. This includes polemic incorporating elements of a word "foreign" and "recent" in the context of the study of hadith, such as hermeneutic approach in understanding Hadith promoted by Dr. Buchari Muchtar which was viewed from his master thesis or criticism of honor as he offered at the doctoral level. This issue appears to be still curiosity and a "heretic" in the discourse of scholars at the beginning of that period. It is similar to Takhrij hadith on messages at Friday pulpit preaching which were rarely encountered in their concentration of the concept of "living tradition" that recently emergence. In essence, scholars of Minang mostly composed works on mushthalah and translation comparing to most Banjar scholars who had greater attention to the compilation of hadith $40 .^{30}$

\section{Inspiration and Challenges of Advanced}

Based on the above explanation, there are several points of instruction that might be picked up and used as the inspiration by today's generations, namely:

1. If the background and focus on Minangkabau scholars are seriously observed, most of them were "born" from the Surau. Indeed, the existence of Surau as a traditional local institution which in fact had issued a lot of great people. Two out of six figures were graduated from Thawalib Sumatera. They learnt auto-didactic and talaqqi with the teacher. They were Zainal Abidin Ahmad and Mawardi Muhammad. When the other two graduated from the Middle East, namely Mahmud Yunus (alumni of the University of al-Azhar and the Darul 'Ulum, Cairo) while Zainuddin Hamidy graduated from Ma'had alIslami and Masjid al-Haram, Mecca. As for the rest, Oemar Bakry graduated from Normal Islam Padang and had studied at the Faculty of Literature, University of Indonesia. While Fachruddin Husain was purely the alumni of Surau, even his rejection from parents' offer to study in the Holy Land indicated that he wanted to learn with the local clergies.

Details for explaining the background and the employment of scholars in the field of hadith are listed chronologically viewed from the birth of the characters, rather than the appearance throughoutthe earliest works.

Table 2: The Background of Figures and the Works on Hadith

\begin{tabular}{|c|c|c|c|c|c|}
\hline No & Names & Alive & Education/Teacher & Works on Hadith & Year \\
\hline \multirow[t]{4}{*}{1} & \multirow[t]{4}{*}{ Mahmud Yunus } & \multirow[t]{4}{*}{$1899-1982$} & $\begin{array}{l}\text { Madras School @ } \\
\text { Sungayang }\end{array}$ & 'Ilm Mustalah al-Hadith & 1941 \\
\hline & & & $\begin{array}{l}\text { Universitas al-Azhar @ } \\
\text { Kairo }\end{array}$ & Ilmu Musthalah Hadis & 1958 \\
\hline & & & \multirow[t]{2}{*}{ Darul ‘Ulum@ @ Kairo } & Doa-doa Rasulullah & 1975 \\
\hline & & & & $\begin{array}{l}\text { Akhlak Menurut al- } \\
\text { Quran dan Hadis }\end{array}$ & 1978 \\
\hline \multirow[t]{3}{*}{2} & \multirow[t]{3}{*}{ Zainuddin Hamidy } & \multirow[t]{3}{*}{$1907-1957$} & $\begin{array}{l}\text { Sumatera Thawalib @ } \\
\text { Padang Japang }\end{array}$ & $\begin{array}{l}\text { Terjemah Hadis Sahih } \\
\text { Bukhari (1-4) }\end{array}$ & 1937 \\
\hline & & & Ma‘had Islami@Makkah & Mushthalah Hadis & - \\
\hline & & & $\begin{array}{l}\text { Masjid al-Haram @ } \\
\text { Makkah }\end{array}$ & $\begin{array}{l}\text { 40 Hadis Pilihan: } \\
\text { Dengan Syarahnya }\end{array}$ & 1956 \\
\hline \multirow[t]{2}{*}{3} & \multirow[t]{2}{*}{ Fachruddin Husain } & \multirow[t]{2}{*}{$1908-1987$} & $\begin{array}{l}\text { Engku Hamzah @ Air } \\
\text { Tabik }\end{array}$ & $\begin{array}{l}\text { Terjemah Hadis Sahih } \\
\text { Muslim (1-4) }\end{array}$ & 1978 \\
\hline & & & Engku Ahmad Karung & Pilihan Sabda Rasul & 1996 \\
\hline
\end{tabular}

${ }^{30}$ Saifuddin et al., "Peta Kajian Hadis Ulama Banjar", in Tashwir, 1 No. 2 (2013): 19. 


\begin{tabular}{|c|c|c|c|c|c|}
\hline \multirow[t]{2}{*}{4} & \multirow[t]{2}{*}{$\begin{array}{l}\text { Zainal Abidin } \\
\text { Ahmad }\end{array}$} & \multirow[t]{2}{*}{$1911-1983$} & $\begin{array}{l}\text { Surau Haji Shaleh @ } \\
\text { Nunang }\end{array}$ & \multirow[t]{2}{*}{$\begin{array}{l}\text { Imam Buchari: } \\
\text { Pemuncak Ilmu Hadis }\end{array}$} & \multirow[t]{2}{*}{1974} \\
\hline & & & $\begin{array}{l}\text { Sumatera Thawalib @ } \\
\text { Padang Panjang }\end{array}$ & & \\
\hline \multirow[t]{6}{*}{5} & \multirow[t]{6}{*}{$\begin{array}{l}\text { Mawardi } \\
\text { Muhammad }\end{array}$} & \multirow[t]{6}{*}{ 1913-1994 } & $\begin{array}{l}\text { Sumatera Thawalib @ } \\
\text { Padang Panjang }\end{array}$ & Hidayah al-Bahith & 1936 \\
\hline & & & \multirow{5}{*}{$\begin{array}{l}\text { Diniyah School @ } \\
\text { Padang Panjang }\end{array}$} & Jawahir al-Ahadith & 1937 \\
\hline & & & & $\begin{array}{l}\text { Al-Ahadith al- } \\
\text { Mukhtarah (1-3) }\end{array}$ & 1951 \\
\hline & & & & Ilmu Musthalah Hadis & 1957 \\
\hline & & & & $\begin{array}{l}\text { Al-Ahadith al- } \\
\text { Mukhtarah wa } \\
\text { Sharhuha (3-6) }\end{array}$ & 1971 \\
\hline & & & & Ma'ani al-Hadith & - \\
\hline \multirow[t]{4}{*}{6} & \multirow[t]{4}{*}{ Oemar Bakry } & \multirow[t]{4}{*}{ 1916-1985 } & $\begin{array}{l}\text { Sumatera Thawalib @ } \\
\text { Padang Panjang }\end{array}$ & Al-Ahadith al-Sahihah & 1938 \\
\hline & & & $\begin{array}{l}\text { Diniyah School @ } \\
\text { Padang Panjang }\end{array}$ & \multirow[t]{3}{*}{ Uraian 50 Hadis } & \multirow[t]{3}{*}{1981} \\
\hline & & & Normal School@ Padang & & \\
\hline & & & $\begin{array}{l}\text { Universitas Indonesia @ } \\
\text { Jakarta }\end{array}$ & & \\
\hline
\end{tabular}

Why is the precedent works necessary for the transformation of today's scholars of Hadith? Referring to their background, the majority of them were Madrasah or Pondok' graduates. By finger counting the scholars regarded themselves to be wanderers of science to the next level. Mahmud Yunus may be taken as the example who continued his studies at the University of al-Azhar and Darul 'Ulum Cairo; Zainuddin Hamidy was studying at Ma'had Islami and the Masjid al-Haram Mecca; Oemar Bakry continued his higher education from Islamic Normal Padang to the University of Indonesia. While the rests were only “certified" as Surau graduates by talaqqi, and also only the alumni of Thawalib and Diniyah School, two secondary-ranking religious teaching institutions. Therefore, it must be admitted that these educational institutions had ever been a center of science and brilliance as well as delivering great figures.

2. Seeing at the cultivated areas of expertise of the above mentioned figures overall, they were also religious leaders. Mahmud Yunus was an expert in Arabic and a reformist in the realm of Islamic education in Indonesia, besides a qualified personnel in the interpretation of the Qur'an. While Zainuddin Hamidy was a writer and an interpreter along with a respected expert on Hadiths of his time. Fachruddin Husain was a freedom fighter and political practitioners diligently translating the work of hadith. Zainal Abidin Ahmad originally known as a journalist, author and political activist. However, the teaching profession cannot slip away, even PTIQ Jakarta had ever raised him as a professor and trusted to be a rector. As for Mawardi Muhammad was a productive clerical educator in generating treasures of al-hadith. While Oemar Bakry was merchant who victoriously cultivated in the field of printing propaganda (writing), even had a brilliant workon Qur'anic exegesis named Tafsir Rahmat.

Good works must be collectively done among generations in order to be lighter. This was the philosophy of "charity jama'i" in the 
Islamic law inherited from previous generations. Minangkabau scholars working pattern had practiced in preparing the repertoire works. Writing collectively or joint essay hadin fact become a privilege in itself. Therefore, no deeds which bear the same weight but teamwork even if a special caravan is formed for initiating responsibility like that. Among scholars who wrote together was Mahmud Yunus and his partner Mahmud Aziz on Science Musthalah Hadith (1958), Fachruddin HS and his son Irfan Fachruddin (now the Chief Justice of the Republic of Indonesia) with their Selected Words of the Apostle (1996), Zainuddin Hamidy, Fachruddin HS, Nasharuddin Taha and colleagues in an effort to complete Translation of Hadith Sahih Bukhari 1-4 (1937).

3. As far as the depth of the study is concerned the earlier scholars (1930-1990s) produced introductory to the study of Hadith with popular languages (not scientific). In addition, most of the treasures were found to be the translation of Arabic literature and not to be "at birth" of the academic tasks but merely in order to obtain a bachelor's degree only. Similar cases touched at them should be taken into consideration for the present generation whenever they write a research paper, such as writing a hadith entitled special (hadith maudu'i). For example, the hadith deals with perspective of the symptoms of committing corruption by state officials, would form a brilliant student in the perspective of hadith, and so forth. What a happy indeed, the majority of the Islamic universities had precisely developed analytical methodology, prominent figures, manuscripts and hadith maudu'i. Hopefully the efforts would not stop with only regards to the extent of the curriculum in order to obtain a degree. Instead, it should be forwarded in writing the next popular and market orientation.

The translation job on the works of classical scholars in order to be understood by people who do not speak the source language had proven the manifestation (expression) of love and high respect to the intellectual heritages. It would be better if this endeavor seriously considered by scientists today at least to give birth to a new breakthrough in terms of writing. Aren't Moslems today faced with ease compared to the earlier generation? There would great transformation when the case was realized well.

4. The development of Hadith literature which were compiled in 1920-1990s much more written in native language with Latin script (Rumi). It was found about $61 \%$ or 11 works arranged in Indonesian out of 18 works were identified. However, another part is $39 \%$ or 7 works written in Arabic. Apparently, this tradition is mostly done by the madrasah teachers for the sake of textbooks. As far as the writing style is concerned, it was applied as Sahlan (easy) and was a concise review (ijaz), so it is not too difficult for students to understand the authors' word meaning and review. The case is somewhat different from treasures produced by Middle East scientists in which many classical scholars used complicated language style that inevitably the target readers desired by the author who wrote the book in Arabic is more spacious. The easily access is not limited solely to learners at the Islamic boarding schools, instead making them more easily accessible to applicants outside the archipelago. Due to the treasures were published by local publisher which was not well known, the treasures were not widely spread in the international Moslem community.

Some books were organized for pedagogical purposes (for teaching) at madrasah, boarding schools and homeland colleges, including 'Ilm Mustalah al-Hadith, Science of Musthalah Hadith and the Prayers of the Messenger among the three books written by Mahmud 
Yunus, all works of hadith by Buya Mawardi, such as the Hidayah al-Bahith, Jawahir alAhadith al-Ahadith al-Mukhtarah 1-3, Musthalah Science of Hadith and al-Ahadith al-Mukhtarah wa Sharhuha 3-6 and similarly, an arrangement treasure by Oemar Bakry, alAhadith al-Sahihah (1938) included in these categories. When it is viewed from the aspect of material benefits, royalties earned were not proportional due to lack of facilities as well as computer applications technology as presented today. Indeed, value sincerity needs to be a role model and inspiration for writers and teachers.

5. It was found that method of quoting the hadiths by most of them were practicing simple tradition, i.e.citing the text of hadith accompanied by the sanad in the ranking of Prophet companions and mukharrij (narrators) of the hadith. In addition, they were also lack of the foundation to review the level and position of the Hadith (whether valid or weak), because their main objective is to convey a moral messages contained in the words of the Prophet PBUH, even if the hadith quoted was about the history of famous priests in the field of hadith, such as al-Bukhari, Muslim, Abu Dawud, al-Tirmidhi, al-Nasa'i and Ibn Majah. Indeed, the works were recorded in intense translation, without citing them perfectly. Therefore, the hadith scholars of recent century need to take a good position to augment the work of the treasury by former Hadith scholars, because their works were still useful to be stared and be the general public references still.

In addition to the cases mentioned earlier, there should be developing ideas as once popularized by Ahmad Lutfi Fathullah regarding the method of writing hadiths that focused on a series of sanad in one book, for example, al-Bukhari $\rightarrow$ 'Abdullah bin Yusuf $\rightarrow$ Malik $\rightarrow$ Nafi' $\rightarrow$ Abdullah bin Umar $\rightarrow$ Prophet Muhammad PBUH in his" 40
Hadith Mudah Dihafal Sanad and Matan (Jakarta: al-Mughni Press, 2014). Even, he wishes to arrange a pedigree system of hadith reported through four lanes. Each lane has 10 to 40 Hadiths. Furthermore, the students of Sheikh Nur al-Din 'Itr has also been developing efforts of "digitization of hadith", a rare touched even unimagined by classical scholars including those of Minangkabau in 1930-1990s. This effort hopefully would necessarily increase public interest in learning hadiths.

Lastly, as implemented by the traditional Islamic boarding schools and scholars of the past, efforts should be made to promote memorization tradition among Moslems. Although it is not an essentially mandatory practice, such as memorizing the Qur'an. At least, the reward can be traditionally applied by means that the Prophet's teachings can be earthed as the sunnah living conception. Why does the racing of reading al-Qur'an should be displayed periodically and regularly? Doesn't the prevalent memorizing of hadiths would make this community more resilient in worship and steady in its Islamic character?

\section{Conclusion}

The tradition of Minangkabau scholars in the preparation work of hadith in the era 1930s to 1980s had spawned treasures of the Sunnah with its own values. Globally, the language and style of writing they had performed were a nonscientific style with popular language, concise and easily retrieved. Unlike the writing of the cuttingedge academic scholars formed the tradition by mentioning referral sources through the foot-note pattern, end-note as well as body-note. Although the classical works of Minangkabau scholars did not appear such a patterns due to the need only to achieve academic strata, it does not mean the works presented were non-scientific value at all. Indeed, the persistence of earlier scholars need to 
be emulated by scholars of institution of higher learning today. Not least among those who hold "flashy" academic titles, but barren in the productivity of scientific papers, but the thesis and dissertation he had presented to qualify for a designation of undergraduate, masters and doctoral degrees. However, if traces gone to the background of previous scholars in writing, in addition to hard ship in obtaining references, no provision of technology, no experience in learning research methodology, they even never think over low royalty sales they got.

Overlooking at figures of scholars coming from Minang at the beginning period of the 20th century, there has been momentum on strengthening the assessment traditions in the country. Although the concerned clergies cannot be considered as Muhaddith as in most of the science of hadith terminology, through writing and teaching, they've got involve in the assessment tradition for enlightening al-hadith. Indeed, their donation was certified by the academic world in improving comprehension and deployment of hadith in the community. By limited space, then another character who was "born" from the "womb" of institutions of higher learning in the 1990-2000s were not told. Their role in the assessment of hadith should not be underestimated. An example for this case is "The history of thought of Hadith" by Professor Edi Safri (Professor of Hadith and the Director of Postgraduate Studies of IAIN Imam Bonjol Padang); Professor Nawir Yuslem (Professor of Hadith and former Director of Postgraduate Studies of IAIN North Sumatra); Buchari Muchtar (Doctor of Hadith at UIN Syarif Hidayatullah is now submissive for the University of Islamic Sciences Malaysia); Urwatul Wusqa (Doctor of Hadith at the National University of Malaysia and lecturer at IAIN Imam Bonjol Padang).
In addition, the writer also found some other scholars who also concerned with the writing of hadith, such as Shekh Isma'il al-Minangkabau who wrote Mawa 'iz al-Badi'ah (Kuala Lumpur: Khazanah Fathaniyah). Ustaz Abdoellatif Soekoer composed al-Ahadith al-Nabawiyah: Seribu Hadith Nabi s.a.w. yang Baik-baik Teratur Menurut Huruf Ejaan (Bukittinggi: Drukkerij Tsamaratoel-Ichwan, 1926). Ustaz Muhammad Kasim Bakry compiled Pelajaran Hadith 1 (Jakarta: Wijaya, 1964; 107 pages); Pelajaran Hadith 2 (Jakarta: Wijaya, 1961; 118 pages). Buya Nasharuddin fabricated Durus Taha al-Hadith (Bukittingi: Maktabah Sa'adiyah); Pribadi Muslim Personal: Mengandungi Uraian 170 Hadith Sahih (Jakarta: Bulan Bintang, 1960; 224 pages). Shekh Yasin al-Fadani, the sanad activists had compiled some of the treasures of hadith such as al-Durr al-Mandud Sharh Sunan Abi Dawud (20 volumes); Fath al-'Allam Bulugh Sharh alMaram (4 volumes); Sadd al-Arab min 'Ulum alIsnad wa al-Adab (Cairo: Matba'ah Hijazi, 1942); Asanid al-Kutub al-Hadithiyah al-Sab'ah (Makkah: Matba'ah al-Nahdah al-Hadithiyah, 1968); Ithaf al-Bararah Asanid bi al-Kutub alHadithiyah al-'Asharah (Damascus: Dar alBasa'ir, 1983); Riyad Ahl al-Jannah bi Athar Ahl al-Sunnah (Damascus: Dar al-Basa'ir, 1985); Arba'un Hadithan min Riyad al-Jannah (Beirut: Dar al-Basha'ir al-Islamiyah, 1985); 'Ujalah alfi al-Ahadith al-Musalsalah (Damascus: Dar alBasa'ir, 1985); Waraqat fi Majmu'ah alMusalsalat (Damascus: Dar al-Basa'ir, 1986); alArba'un al-Buldaniyah (Beirut: Dar al-Basha'ir al-Islamiyah, 1987); al-Asanid al-Makkiyah li Kutub al-Hadith (Beirut: Dar al-Basha'ir alIslamiyah, 1989); and al-Arba'un Hadithan (Beirut: Dar al-Basha'ir al-Islamiyah, 2008). Hopefully, in a future articles, the scholars and their complete works of hadith can also be introduced. 


\section{Bibliography}

Abuddin Nata. Tokoh-tokoh Pembaruan Pendidikan Islam di Indonesia. Jakarta: Raja Grafindo Persada, 2005.

Azyumardi Azra. Pendidikan Islam: Tradisi dan Modernisasi Menuju Milenium Baru. Cet.

4. Jakarta: Logos Wacana Ilmu, 2002.

Eficandra Masril. "Prof. Dr. H. Mahmud Yunus: Tokoh Mujaddid dari Minangkabau”. Makalah dalam Nadwah Ulama Nusantara IV: Ulama Pemacu Transformasi Negara, Jabatan Pengajian Arab dan Tamadun Islam, Fakulti Pengajian Islam, Universiti Kebangsaan Malaysia, 25-26 November 2011.

Fachri Fachruddin. Anak kelima Fachruddin HS dan Sari Bulan. wawancara, 7 Maret 2015.

Fachruddin HS. Terjemah Hadis Sahih Muslim 1-4. Jakarta: Bulan Bintang, 1978.

Fachruddin HS. dan Irfan Fachruddin. Pilihan Sabda Rasul (Hadis-hadis Pilihan). Jakarta: Bumi Aksara. 1996.

Fahmi Oemar. Anak keempat Oemar Bakry dan Nurjannah serta Direktur Mutiara Sumber Widya Jakarta. wawancara, 22 Juli 2012 dan 31 Oktober 2012.

Federspiel, Howard M. Kajian Al-Quran di Indonesia Dari Mahmud Yunus Hingga Quraish Shihab. Tajul Arifin (pent.). Cet. 2. Bandung: Mizan, 1996.

Hikmat Israr. Angku Mudo Haji Zainuddin Hamidy: Pejuang Agama dan Pendiri Ma 'had Islamy Payakumbuh. Bandung: Budaya Media, 2010.

Isnawati Rais. Pemikiran Fikih Abdul Hamid Hakim. Jakarta: Depertemen Agama RI, 2005.

Jannatul Husna bin Ali Nuar. "Syeikh Yasin
Padang dan Hadis Arba'in: Ulasan dan Takhrij" dalam Fauzi bin Deraman et al. (eds.), Sunnah Nabi: Realiti dan Cabaran Semasa, Kuala Lumpur: Universiti Malaya, 2011.

. "Buya Haji Mawardi: Khidmatnya Terhadap Sunnah Nabi" dalam Khadher bin Ahmad dan Sedek bin Ariffin (eds.), Transformasi Penyelidikan dalam Bidang Pengajian Islam. Kuala Lumpur: Universiti Malaya, 2012.

. "Analisis Hadis Terpilih dalam Karya Buya Mawardi" dalam Khadher bin Ahmad et al. (eds.), Sunnah Nabawiah: Survival dan Cabaran. Kuala Lumpur: Universiti Malaya, 2013.

. "Pemikiran Hadis Buya Mawardi Muhammad: Analisis Kitab al-Ahadith alMukhtarah wa Sharhuha Jilid Ketiga" dalam Hajah Tiara Basman dan Muslihuddin Syah Mustafa (eds.), Memperkasa Pendidikan Usuluddin: Isu dan Cabaran Semasa. Bandar Seri Begawan: Kolej Universiti Perguruan Ugama Seri Begawan, 2014.

. Ustaz Haji Oemar Bakry dan Uraian 50 Hadis. Jakarta: Mutiara Sumber Widya, 2015.

MahmudAziz dan Mahmud Yunus. Ilmu Musthalah Hadis. cet. 8. Jakarta: Jayamurni, 1975.

Mahmud Yunus. Sejarah Pendidikan Islam di Indonesia. Jakarta: Pustaka Mahmudiah, 1960 .

. 'Ilm Mustalah al-Hadith. cet. 3. Padang Panjang: Maktabah Sa'adiyah, 1969.

- Tafsir Quran Karim. Cet. 19. Singapore: Basheer Ahamed, 1979. . Riwayat Hidup Prof. Dr. H. Mahmud Yunus: 10 Pebruari 1899-16 Januari 1982. Jakarta: Hidakarya Agung, 1982. 
Mawardi Muhammad. al-Ahadith al-Mukhtarah. Juz. 1-3. Padang: Percetakan Sridharma, t.th. - al-Ahadith al-Mukhtarah wa Sharhuha. Juz. 3-6. Padang Panjang: Penerbit Sa'adiyah Putra, t.th.

- Hidayah al-Bahith fi Mustalah alHadith. Cet. 11. Bukittinggi: Pustaka Sa'adijah, 1972.

. Ilmu Mushthalah Hadis. Bukittinggi: Pustaka Sa'adijah, 1957. . Jawahiral-Ahadith al-Nabawiyah.

Cet. 7. Padang Panjang: Penerbit Tandikat, t.th.

Nukman. "Profil Syekh Haji Zainuddin Hamidy" dalam Edwar (ed.). Riwayat Hidup dan Perjuangan 20 Ulama Besar Sumatera Barat. Padang: Islamic Centre Sumatera Barat, 1981.

Oemar Bakry. Uraian 50 Hadis. Jakarta: Penerbit Mutiara, 1981. . Tafsir Rahmat. Cet. 3. Jakarta: Penerbit Mutiara, 1984.
. Dari Thawalib ke Dunia Modern. Jakarta dan Bandung: Penerbit Mutiara dan Angkasa, t.th.

Ramayulis dan Samsul Nizar. Ensiklopedi Tokoh Pendidikan Islam: Mengenal Tokoh Pendidikan Islam di Dunia Islam dan Indonesia. Jakarta: Quantum Teaching, 2010.

Ramzi Zainuddin. Anak keempat Zainuddin Hamidy dan Rahmah serta Pimpinan Ma'had Islamy Payakumbuh. Wawancara, 02 Juli 2012

Saifuddin et. al. "Peta Kajian Hadis Ulama Banjar”. Tashwir 1, no. 2 (2013): 19.

Soebagijo Ilham. Riwayat Hidup dan Perjuangan Haji Zainal Abidin Ahmad. Jakarta: Pustaka Antara, 1985.

Zainal Abidin Ahmad. Imam Bukhari: Pemuncak Ilmu Hadis. Jakarta: Bulan Bintang, 1975.

Zainuddin Hamidy. 40 Hadis Pilihan: Dengan Sjarahnya. Jakarta: Penerbit Jayabakti, 1956. . et. al. Terjemah Hadis Sahih Bukhari 1-4. Singapore: Darel Fajr Publishing House, 2009. 